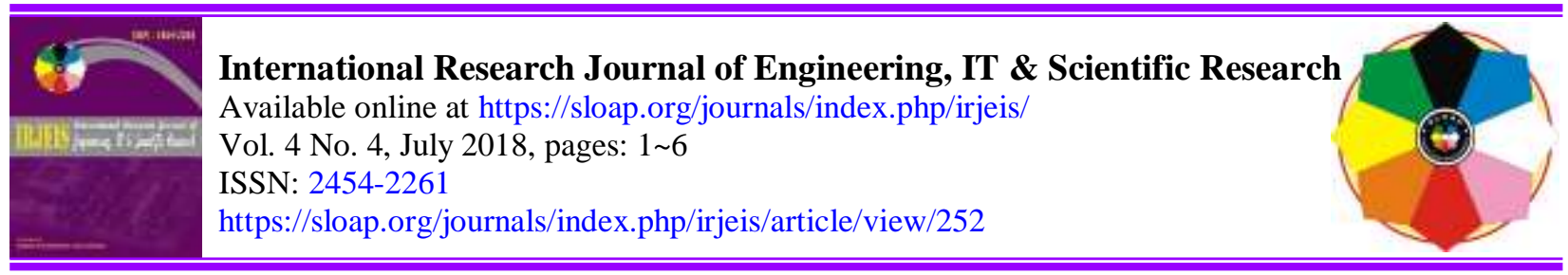

\title{
Mechanical Properties of Artisanal Bricks
}

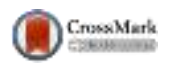

\author{
Wilter Enrique Ruíz Párraga a \\ María Soledad Azúa Campos ${ }^{\text {b }}$ \\ Eduardo Humberto Ortiz Hernández ${ }^{c}$
}

Article history:

Received: 14 February 2018

Revised: 10 June 2018

Approved: 27 June 2018

Published: 29 June 2018

Keywords:

Clay;

Bricks;

Bending;

Moisture;

Brickwork;

Absorption;

Compression;

\section{Abstract}

One of the problems facing construction now is obtaining materials that meet certain conditions of durability and resistance, before weathering or natural phenomena, this work shows the study of the mechanical properties of clay bricks that have were made by hand, between three different brickyards near the Portoviejo canton, here a comparison is made by applying the Ecuadorian standards. The tests allowed performing the comparisons of moisture absorption, compression resistance, and flexural strength test. Field visits, interviews, laboratory tests and tabulation of results have were used as a methodology. The software has was used to make the graphs and statistical tables for its interpretation. As a result of the research, it was found that of the three artisan brick kilns studied. They only meet one of the three criteria established by the INEN. The test that showed the best results was the resistance to bending, while the absorption moisture and resistance to compression results that are below the parameters established in the standard, a situation that is of interest to the community, because a large percentage of the population close to these artisan brick kilns, build their homes with this material.

2454-2261 ${ }^{\circ}$ Copyright 2018. The Author. This is an open-access article under the CC BY-SA license (https://creativecommons.org/licenses/by-sa/4.0/) All rights reserved.

\section{Author correspondence:}

Wilter Enrique Ruíz Párraga,

Civil Engineering, Faculty of Science, Mathematics, Physics and Chemistry,

Universidad Técnica de Manabí, Portoviejo, Manabí, Ecuador,

Email address:wruiz@utm.edu.ec

\section{Introduction}

Brick is the oldest building material manufactured by man [1]. In the first times, it was started by elaborating it in its raw form, which is the adobe. Its diffusion was due to the fact that the man gave it a size that suited his hand and to do so he resorted to raw materials, which are accessible.

a Civil Engineering, Faculty of Science, Mathematics, Physics and Chemistry, Universidad Técnica de Manabí, Ecuador

b Computer Systems Engineer, Academic Analyst of the Institutional Planning Department of the Universidad Técnica de Manabí

c Aspirant to Ph.D., Civil Engineering, Faculty of Science, Mathematics, Physics and Chemistry. Universidad Técnica de Manabí, Ecuador 
The brick-making activity is widely distributed in Ecuador. The vast majority of micro and small brick companies use artisan techniques to manufacture their products, the manufacturing plants are basically represented by the artisanal oven they make and a space of land for the work and location of the raw material, the same They consist of: water, clay, sawdust and sometimes rice husk is used.

In the investigation, he made a series of tests that allowed to determine the values of the absorption coefficient and other acoustic properties of some building materials in Ecuador, taking as a reference material the common brick and the industrial brick with which I made a study comparative among them [2].

Variations were made regarding its quality since in the case of the artisan brick each one had a different color and consistency and at the time of cutting they reacted differently. Regarding industrial bricks, there were also variations in their quality [3]. In their research, they demonstrated that clay blocks (bricks) can be reused, replacing up to 5\% of the cement with clay powder in a concrete mixture of structural type. The studied waste can be reused in the concrete of non-structural type in proportions of 10 and 15\%. In addition, in their work they concluded that the reuse of these materials helps to mitigate the environmental impact generated by the exploitation of the raw material in the manufacture of cement, also improving the quality of life of people.

Brickmakers must ensure compliance with the quality standards established by the Ecuadorian Institute for Standardization (INEN) [4], [5], [6], [7], [8]; as well as the checklists, controls, tests and tests that must be carried out in parallel and simultaneous to the processes of elaboration of these. The quality control of the artisan brick production identifies the design and execution characteristics that will allow verifying compliance with the level required for each of the stages of the construction process and for its useful life.

With this research work, it was identified which of the three variants of handicraft bricks (Maletón, Maleta, Burrito) meet the requirements established by the INEN, in terms of processing and cooking including the physical and mechanical properties that these must meet. materials.

\section{Research Methods}

To carry out the research, three of the brick factories with the largest production of handmade bricks were selected and they are also located in the periphery of the city of Portoviejo, for this work. The different types of cooked bricks made in the brickworks were taken into account, the same ones that were labeled with the names of bricks Maleta, Burrito, and Maletón, names with which they are known in the sector of study, the tests to be carried out were the established ones by the Ecuadorian standard regarding the quality of materials and designs [4].

The tests carried out are included in the Ecuadorian technical standards for the construction of bricks, which are: Ceramic brick sampling NTE INEN 292: 2015 [4]. Ceramic bricks definitions classification and general conditions. INEN 293 1977-05 [4], ceramic bricks determination of compressive strength. INEN 294 1977-05 [4], ceramic brick determination of flexural strength INEN 295 1977-05. Ceramic bricks determination of moisture absorption NTE INEN 296: 2015 [5][6][7][8].

The tests were carried out in the Hormigón laboratory of the Civil Engineering career, of the faculty of Mathematical and Physical Sciences of the University. The collection of samples for their tests in the laboratory were carried out randomly in the different brickworks under study and thus be able to carry out the comparative analysis between what exists and what is regulated by the INEN.

The number of samples by tests and brickwork was governed by the norm, leaving 5 bricks of each type for each artisanal brick, ie 45 samples were taken for each type of test.

\section{Results and Analysis}

Brick is the most accepted building material and used by bricklayers and workers for a long time since it has characteristics of thermal and acoustic insulation that make it a very dynamic material in construction both for walls, walls, and structures. as to make exterior coatings of houses and buildings.

The mud brick is the construction material most used in the construction of the homes of the inhabitants of the Ecuadorian north, however, the manufacture of this is a trade that is diminished by the appearance of new construction techniques [6].

Craft or manual bricks have the rough appearance and their faces are rough, these are obtained by the molding, drying and firing at high temperatures of a clayey paste. Its measures are diverse and manufactured in a size that allows to handle them with one hand by the operator, its dimensions are depending on where they are going to be placed (walls, ceilings, etc.). 
Among the raw materials used for the production of bricks are mainly clay, water, sawdust and rice husks; but the same combinations of the Portoviejo sector do not apply to all the brickyards.

One of the characteristics to evaluate in clays is the chemical and mineralogical composition since it directly influences the properties of the obtained ceramics. Because a clay with high content of kaolin will allow to obtain ceramic products with refractory character, clear coloration and good mechanical resistance, while high contents of illite and montmorillonite confer high plasticity to the ceramic pastes, which translates into an easy confirmation of the pieces, but also in a large contraction of the same during drying and sintering, which can lead to the formation of cracks; in such cases, decreasing material such as sand should be added to adjust the plasticity of the paste.

The properties to be analyzed in the artisanal bricks are related to the guidelines given by the Ecuadorian standards INEN, these are the absorption of humidity of the bricks, resistance to compression forces and resistance to tensile forces,

The evaluation of the characteristics for the absorption of artisanal bricks was carried out based on the maximum absorption value with a percentage greater than $25 \%$ of the INEN regulations.

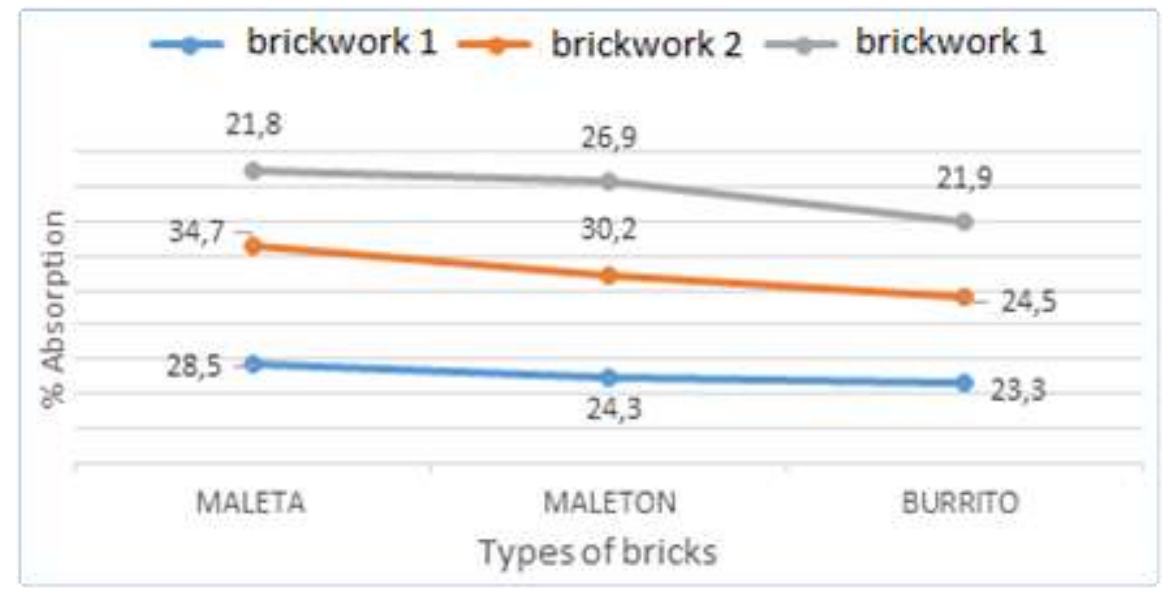

Figure 1. Percentage of moisture absorption

The values shown in Figure 1 indicate that the bricks that come closest to those established by the norm are those made in the Brickyard 3, while the other two artisanal companies, their values are close to or are higher than $25 \%$ established in the NTE INEN 296: 2015 [7].

According to the Ecuadorian Standardization Institute INEN 297 1977-05 [8], the determinations of the compressive strength of the bricks must have a minimum of $8 \mathrm{MPa}$, on the average of 5 bricks tested, and a minimum of $6 \mathrm{MPa}$ for each sample individual in figure 2 shows the resistance to the understanding of the bricks built in the three different brickworks.

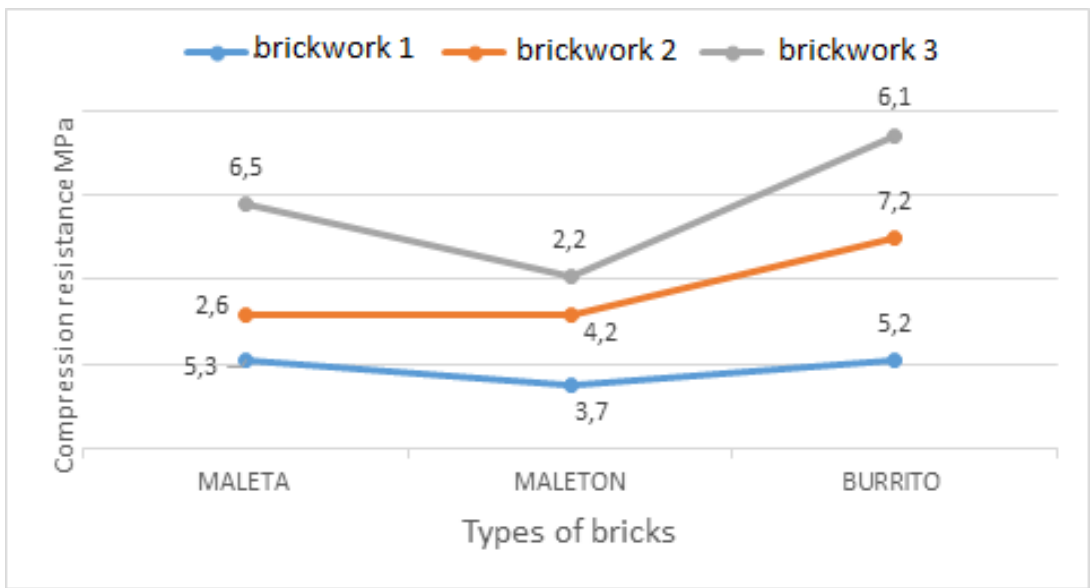

Figure 2. Compression resistance test

Párraga, W. E. R., Campos, M. S. A., \& Hernández, E. H. O. (2018). Mechanical properties of artisanal bricks. International Research Journal of Engineering, IT \& Scientific Research, 4(4), 1-6. https://doi.org/10.21744/irjeis.v4n4.252 
When analyzing Figure 2, it can be concluded that none of the brickworks under study complies, with the provisions of the standard, regarding the value of 8 MPA, on average, an aspect that must be taken into account when selecting the material and of the canter ronde is extracted.

In Figure 3, the results obtained in the tests carried out on the flexural strength have were shown.

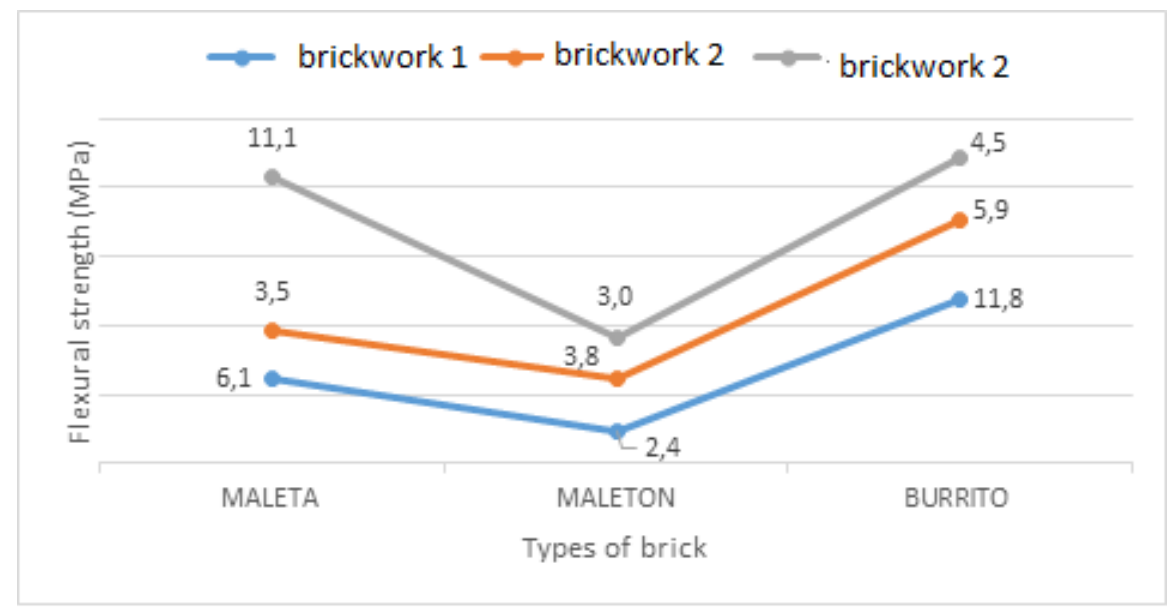

Figure 3. Bending resistance test

The determinations of the flexural strength of the bricks must have a minimum of $2 \mathrm{MPa}$ in the average of 5 bricks tested according to the INEN 297 1977-05 standard [8][19][20][21]. In figure 3, it had was visualized that the three brickworks in the study all comply with the stipulations of the norm regarding the bending of artisan bricks.

In the social field, these results of the trials will allow the artisan brick kilns to improve the ways of making the bricks and these will have an impact on obtaining better quality masonry that will resist the weathering as well as the natural phenomena affecting the canton and the province.

This research generates new and interesting information for the community, because it reveals the criteria that have currently used in artisan brick kilns with the stipulations of the Ecuadorian Institute of Normalization (INEN)

\section{Conclusion}

In the moisture absorption tests, two of the three brickyards under study does not meet the parameters established by NTE INEN 296: 2015, which establishes a maximum percentage of $25 \%$.

From the compression resistance test stipulated in the NTE INEN 294 1977-05, none of the artisanal brickwork that was studied meets the minimum resistance requirement of $8 \mathrm{MPa}$ according to the samples analyzed.

From the test of resistance to flexion established NTE INEN 295 1977-05, it is concluded that the three brickworks meet the minimum criterion of $2 \mathrm{MPa}$, this being an important parameter in the analysis of this masonry.

\section{Conflict of interest statement and funding sources}

The authors declared that they have no competing interest. The study was financed by the authors themselves.

\section{Statement of authorship}

The authors have a responsibility for the conception and design of the study. The authors have approved the final article.

\section{Acknowledgments}

The authors thank the editor of the journal for their valuable time and advice. 
References

1. Gutiérrez, R. S. R. (2016). Construcción sustentable, análisis de retraso térmico a bloques de tierra comprimidos. Contexto: revista de la Facultad de Arquitectura Universidad Autónoma de Nuevo León, 9(11), 5971.

2. Párraga, W., Párraga, M., Salazar, M., \& Albear, J. (2017). Reusing the Coconut Clay (Brick) as Construction Material. International Research Journal Of Engineering, IT \& Scientific Research (IRJEIS), 3(4), 92-98. doi:10.21744/irjeis.v3i4.512

3. Amigó, V. Acción de coordinación de proyectos de investigación 307AC307. Residuos agroindustriales: fuente sostenible de materiales de construcción (Valores).

4. N.D. (2016. «NTE INEN 0696,» de Instituto Ecuatoriano de Normalización, Quito, 2011. View (PDF)

5. N.D. (2016. «NTE INEN 0858,» de Instituto Ecuatoriano de Normalización, Quito, 2010. View (PDF)

6. Clinical Outcomes of Surgical Therapy Study Group. (2004). A comparison of laparoscopically assisted and open colectomy for colon cancer. New England Journal of Medicine, 350(20), 2050-2059. View (PDF)

7. N.D. (2016. «NTE INEN 0857,» de Instituto Ecuatoriano de Normalización., Quito,

8. N.D. (2016. «NTE INEN 0862,» de Instituto Ecuatoriano de Normalización, Quito, 2011. View (PDF)

9. N.D., «NET INEN 0856,» de Instituto Ecuatoriano de Normalización, Quito, 2010. View (PDF)

10. Uquillas Pérez, R. B. (2013). Diseño de una metodología para la valoración de empresas de servicios en el Ecuador(Bachelor's thesis).

11. Camposano, J. (2009). Notas técnicas, control de calidad en el hormigón. Control por resistencia Parte I). EcuadorQuito: INECYC.

12. Crespo, M. F. B. Caracterización Térmica y Mecánica de materiales de construcción mas usados en Ecuador. Materiales para piso y pared.

13. Salazar Carrera, P. J. (2015). Fabricación de ladrillos cerámicos utilizando como aditivos rotura y lodos de la planta de tratamiento de agua de la empresa EDESA SA (Bachelor's thesis, Quito: UCE).

14. Ecuatoriana, N. (1977). Ladrillos cerámicos. Requisitos. Norma INEN, 297, 1977-05.

15. Escobar Sandoval, J. A. (2016). Determinación Del Módulo Elástico Estático Del Concreto En Laboratorio (Bachelor's thesis).

16. Acero, D. (2002). Instituto ecuatoriano de Normalización.

17. Jara, N. G., Reinoso, F. Z., Isaza-Roldan, C., Aguinaga, Á., Duque, M., Llulluna, F., \& Moreno, T. (2016). Laboratorio de pruebas para artefactos de refrigeración doméstica en el Ecuador.

18. Calderón Cañar, E. (2015). Diseño de hormigón con cantos rodados provenientes del río Chanchan a través de los métodos ACI Y O'REILLY (Master's thesis, Universidad de Guayaquil: Facultad de Arquitectura y Urbanismo).

19. Omer, A. M. (2017). Identifying, Developing, and Moving Sustainable Communities through Application of Bioenergy for Energy or Materials: Future Perspective through Energy Efficiency. International Journal of Life Sciences (IJLS), 1(1), 9-39.

20. Palma, C. A. M., Pérez, A. V., Gámez, M. R., \& Torres, L. T. M. (2018). A House A Small Company. International Journal of Physical Sciences and Engineering (IJPSE), 2(1), 26-34.

21. Omer, A. M. (2017). Sustainable Development and Environmentally Friendly Energy Systems. International Journal of Physical Sciences and Engineering (IJPSE), 1(1), 1-39.

Párraga, W. E. R., Campos, M. S. A., \& Hernández, E. H. O. (2018). Mechanical properties of artisanal bricks. International Research Journal of Engineering, IT \& Scientific Research, 4(4), 1-6.

https://doi.org/10.21744/irjeis.v4n4.252 
Biography of Authors

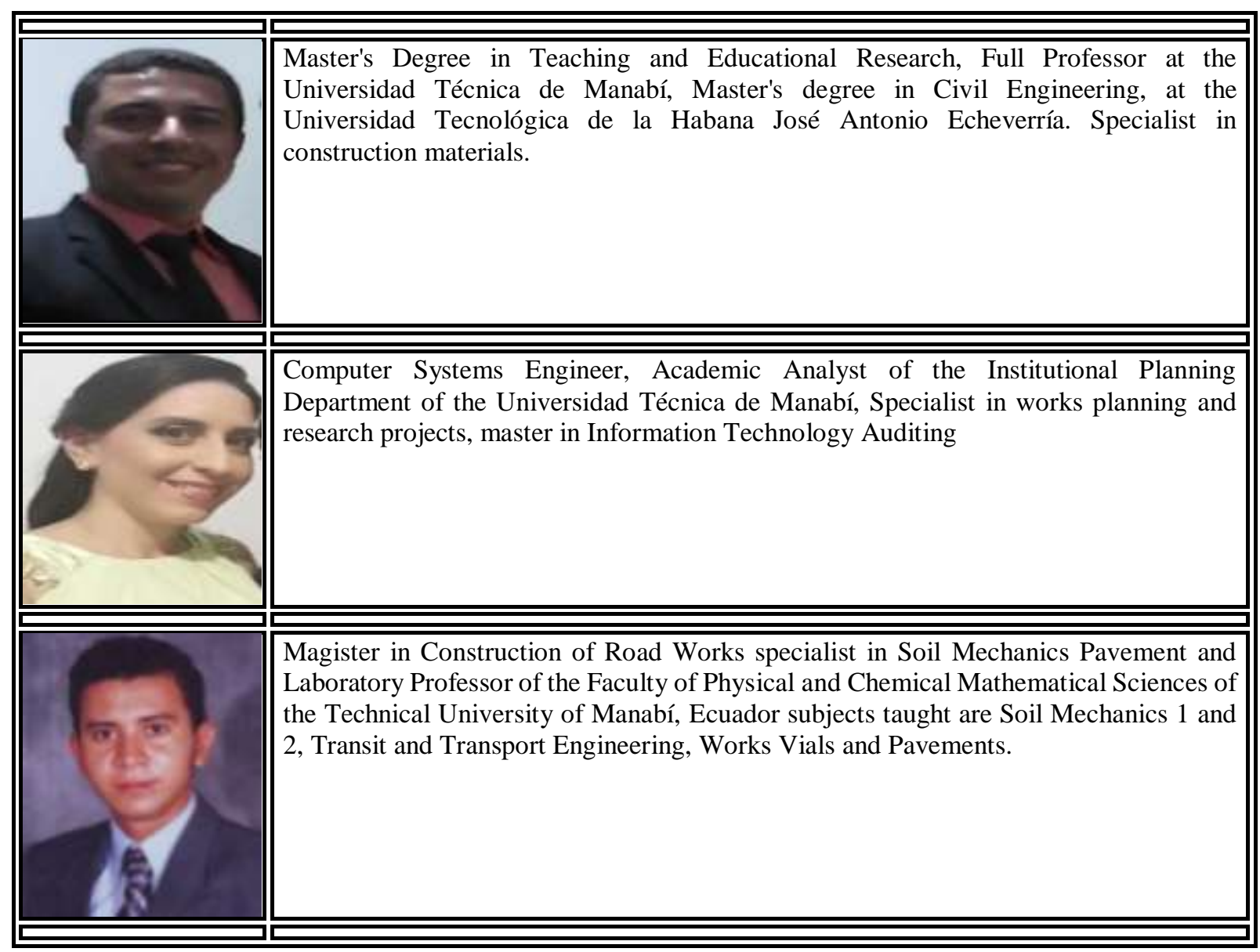

